\title{
Leading creative people: lessons from advertising guru Jacques Séguéla
}

\author{
Christophe Haag ${ }^{a}$, Jean-Francois Coget ${ }^{b}$
}

a EMLYON Business School, 23 Avenue Guy de Collongue, 69134 Ecully cedex, France

b California Polytechnic State University, Orfalea College of Business, San Luis Obispo, CA 93407, USA

\author{
KEYWORDS \\ Leadership; \\ Creativity; \\ Advertising; \\ Emotion; \\ Emotional intelligence; \\ Intuition; \\ Sensemaking
}

\begin{abstract}
Summary In this article, we explore perspectives on how to lead creative people through examples from a practitioner. We interviewed iconic French advertising guru Jacques Séguéla, Chief Communication Officer of Havas, France's second largest and the world's sixth largest advertising and communication company, who leads 800 designers worldwide. Séguéla is famous for creating successful advertising and political campaigns, and authoring numerous best-selling books on advertising. Through a series of real-life anecdotes, Séguéla talks about the importance of emotions, emotional intelligence, action, and intuition in leading creative people. Following the interview, we discuss some of Séguéla's key assertions in relation to existing leadership and management theories.
\end{abstract}

\begin{abstract}
"Creativity is like the Yeti [...] suddenly you see it. Your hairs stand on end, you're out of breath. Here it is! Perhaps it's ugly, perhaps monstrous. Perhaps it doesn't exist. But it doesn't matter. It's there and you've seen it. From this point on you have to sell the Yeti, die for the Yeti. The Yeti must exist.",
\end{abstract}

\section{Introduction}

Creativity, always an important factor for organizational success, has now become critical. As product cycles shorten and global competition intensifies, the economy is becoming increasingly innovation driven (Brown and Eisenhardt,
1997; Tushman and O'Reilly, 1997). In such a context, creativity and innovation help organizations survive discontinuous change and prosper (Nystrom, 1990; Tushman and Anderson, 1986; Drazin and Schoonhoven, 1996).

Academics have thus put a great deal of attention towards understanding the process of creativity (e.g. Amabile, 1996, 1983; Csikszentmihalyi, 1996) and the environments that foster and support it (e.g. Amabile et al., 1996). However, less attention has been paid to how one can manage and lead creative people. Creative people are different from other employees in many regards. They tend to have high levels of expertise (Feldman, 1999), to have their identity bound up in their work (Rostan, 1998), high achieve- 
ment motives, but lower affiliation and power motives (Harrell and Stahl, 1981), and to require a great deal of autonomy (Greenberg, 1992; Oldham and Cummings, 1996). For these reasons, a traditional view is that creative people should not be managed or led at all, but instead left alone (Mumford et al., 2002). Some researchers, however, disagree and have tackled the question of how creative people should be led (e.g. Amabile and Khaire, 2008; Florida and Goodnight, 2005; Goffee and Jones, 2007; Mumford et al., 2002).

In an extensive review of the literature, Mumford and his colleagues (2002) identified four different perspectives on the role that leaders should play with regard to creative people: (1) leave them alone, (2) simply support and facilitate their work, (3) inspire them by providing a vision, or (4) model the way by being creative or technical gurus themselves. In an attempt at integrating these fours perspectives, they suggest that leaders of creative people should: (1) elicit and support idea generation, (2) structure ideas, and (3) promote ideas. Summarizing key insights from a colloquium at Harvard Business School, Amabile and Khaire (2008) suggest that leaders of creative people should tap ideas from all ranks, encourage diversity, protect creatives from bureaucracy, impose control at the end of the creative process rather than at the beginning, and create filtering mechanisms to select commercially viable ideas. After interviewing CEOs of highly innovative companies, Goffee and Jones (2007) suggest that the best way to lead creatives is to reduce administrative distractions, make it safe for them to fail, let them pursue private efforts, and for leaders to demonstrate their own creativity and expertise. Finally, Florida and Goodnight (2005) analyzed how leaders at SAS software company manage creative people: they stimulate them with challenges, they include managers in creative efforts (e.g. the CEO writes code), and they engage customers in the creative effort too (by collecting extensive feedback from them).

In order to complement these efforts to understand how creatives should be led, we decided to interview an icon of the French advertising world: Jacques Séguéla. First, we were intrigued about hearing the point of view of a practitioner rather than academics. Second, we wanted to understand how to lead creativity in the particular industry of advertising and communication. Third, we wondered whether the French cultural context would offer different conclusions than research led mostly in North America.

Séguéla began his career as a reporter for Paris-Match and France-Soir. ${ }^{2}$ In 1969, he co-created RSCG, one of France's most visible advertising agencies, and authored numerous best-selling books on the topic. Séguéla was involved in 20 presidential campaigns in France and abroad, with clientele such as French President François Mitterand in 1981 and Israeli Prime Minister Ehud Barack in 1999. Today, Jacques Séguéla is CCO (Chief Communication Officer) of Havas, France's second largest and the world's sixth largest advertising and communication group, and leads a task force of 800 creative people around the world. We met with Jacques Séguéla in his Paris office and invited him to speak candidly about how he leads creative people. Following the interview, we discuss some of Séguéla's key assertions about how to lead creative people.

\footnotetext{
${ }^{2}$ Two of France's most famous magazines.
}

\section{Interview}

Jacques Séguéla (JS): I'm wary of the word intellect. If it means hard line intelligence, then it is negative in terms of creativity. In fact, really great creators are not usually very intelligent people, which doesn't mean that they're stupid, but rather that they've got another form of intelligence. CEOs or CFOs need several types of intelligence: one that relates to figures, one that relates to people, and a kind of velocity of intelligence that allows them to move faster than others in business discussions. Creative people, on the other hand, work differently. They are sponges. You talk to them. You saturate them. You let them sit, incubate, and come back to you with their ideas.

As far as I'm concerned, I never thought that I was intelligent. l've accepted it as a fact. My cultural knowledge is fairly limited and I don't have this extraordinary velocity of intellect that I see in Mitterrand, ${ }^{3}$ Attali, ${ }^{4}$ Giscard d'Estaing $^{5}$ and all those people l've worked with and who think at 300 kilometers per hour. Sometimes I realize that I just don't understand what's being said. So l've always had to fall back on my instinct. Sometimes, an advertiser talks to me for an hour and I don't understand a word they're saying. When they're finished and ask me "Could you sum up for me?", I rely solely on my instinct and they often say: "You're right, you're telling me what I didn't think about, but that I wanted to say." So it's my frustration of not understanding that makes me push a button somewhere inside me that does the understanding for me. It's the heart that understands, the imagination, not the mind. I've always worked like that. When somebody asks me a question, I stop myself from reasoning. I react, and I think about it afterwards.

Interviewer: How do you control decisions that happen in such a spontaneous manner?

JS: I don't control them! When somebody asks me a question, I reply, and then, afterwards, I think about it and I don't always agree with what I've said. This is why I criticize intelligent people. They believe that because they've thought about their opinion, it must be right. Wrong! They can make mistakes like everybody else. So, as far as I'm concerned, I spontaneously speak what my gut says, then I analyze it, and I face up to it. I'm ready to change my point of view without any problem. However, if I feel I was right, I couldn't care less whether people agree or disagree with me! It's what I think. I go on thinking it. I go on saying it. I'm not here to be nice to people. I'm here quite simply to be as I am. If you like what you see, you can have me and you won't be misled.

Interviewer: What qualities do you need to lead creative people?

JS: Leaders of creative people should, above all, have emotional intelligence (EQ). IQ is being able to think about things faster than others, thus putting yourself above others. But for me, EQ is putting yourself in direct contact with others; touching each other's fingers. If I had to choose a symbol to define EQ, it would be that of Michelangelo's Sistine's Chapel's fresco: the knowledge of a god that com-

\footnotetext{
${ }^{3}$ French president between 1981 and 1995.

${ }^{4}$ Famous French intellectual, advisor to Francois Mitterrand.

${ }^{5}$ French president between 1974 and 1981.
} 
pletely understands the innocence of a small boy. If you take a close look at politicians, you'll notice that the ones that succeed are never cold-blooded animals. I knew François Mitterrand well and he had, first and foremost EQ, even though he hid it because you don't have to reveal your emotions to be emotionally intelligent. I think that we live in a world that is increasingly passionate, increasingly human, increasingly able to listen. We face bigger and bigger challenges and it's not IQ that can address them, but rather EQ; our ability to put ourselves in other people's shoes. I think that the 21st century will belong to emotionally intelligent people.

I'm a good salesman because you can't be creative if you don't defend your ideas. I try to have some ideas myself, and I have 800 people around the world to help me produce ideas, which is a lot of people. But an idea only exists if it's out there, on walls, on the screen. My real job is to be ready to die if I haven't sold a great idea when we have one. I put my heart and soul into selling great ideas.

Of course, like all great salesmen I'm a terrible buyer because good sales pitches move me. I'm capable of buying everything if the salesperson is good. I rely totally on emotion to make myself heard and to understand, so when I have to make a big decision for my company, where 18,000 employees could suffer the consequences of a bad decision, I try to think about my sentiment, and then to listen to others. Even on creative subjects, I go across the corridor to see one of my early days partners, and I tell him: "I have a serious doubt about this ad campaign. Can you tell me in 30 seconds what you think about it?' Then I go see the CFO next door and I tell him: "I'm lost here, what can you tell me?" Then I go down to see just anyone I come across in the agency. I do my little tour, that's how I test my ideas. When I'm done, l've already taken my decision.

I confront my decision with the views of others and I change my mind if I feel it's not going to work, if it's a bad decision. However, if I think too much about it, I'm no longer able to make a decision because l'll tell myself: "Well, there's this but there could also be that", or "Yes, I prefer this video, but this other one's not bad either, and there's that other one as well" - it's hopeless. That's not what's expected from me. Every day I have creative people who come to see me expecting me to decide, to choose. We always put several teams in competition with each other. So they're here, they present their campaign and they expect me to say this one will work, but not that one, and then to argue about it a bit. I try to explain why I think this one's going to work. But they accept that I can make mistakes like anyone else, except that my job is to make less mistakes than others, because if I'm wrong each time we will lose customers.

l've been in advertising for 40 years now and l've made all the stupid mistakes that you can make in this business not once but 10 times. I've also been going around the world for 20 years to see what others are doing, to visit our agencies. So, all the stupid mistakes that have been made in advertising, I've seen them made 10 times over by others. So I'm beginning to have a certain amount of knowledge, to be able to judge things.

At the same time, I know full well that the only rule in creativity is that there aren't any rules. It's not because something's failed 100 times over that it won't work today.
If, suddenly, my heart goes for something, I'll say: "Forget everything, everything I could know, everything I've been able to understand, everything I've been able to learn. We'll do this!" That's why I like to say "'less testing, more testicles." If you ask the public to choose for you each time, they'll always choose the middle option, the smallest common denominator. So, at some point, you need to have the guts to say: "We'll do this!" That's the only way it can work. I'm often asked for the definition of creativity. I respond that creation is like the Yeti. Nobody's ever seen the Yeti. But imagine that the Yeti comes in here, and then crosses the camera field. You, you'll rush out to sell to the world not this interview, but the Yeti instead. You'll say: "I've filmed the Yeti!"' It'll make headlines all over the world! Creativity is like the Yeti. It is the Yeti. You watch things, and then suddenly you see it. Your hairs stand on end, you're out of breath. Here it is! Perhaps it's ugly, perhaps monstrous. Perhaps it doesn't exist. But it doesn't matter. It's there and you've seen it. From this point on you have to sell the Yeti, die for the Yeti. The Yeti must exist. But then, you'd better not be mistaken about the Yeti too many times; otherwise things will go south for you.

Interviewer: So, how do you lead your creatives?

JS: My most important principle is for creatives to tell me when something's wrong... I'm not saying that everybody tells me everything that's going on all of the time, but my creatives know that they can tell me everything, which is already a great start. I'm a bit like their shrink so as soon as there's a drama in a couple I'm the first to know. I patch things up between some of them from time to time. I'll say: "Quit being stupid, I'll invite you and your partner for some spaghetti, we'll chat things over, what's going on and then if it's work that's part of the problem we'll make some arrangements, we'll sort things out, if they're fed up seeing you come home at midnight every night, we'll reduce some of your workload." You can only create if you're happy.

At the same time, creation must be nerve-wracking. I don't stop myself from putting real pressure on my designers. I tell them that if they're no good I'll fire them. I'll say to them: "You're completely useless, I've never seen such a pathetic ad campaign."' After all, that's Sarkozy's method. Hold a stick in one hand, and chocolate in the other.

Then, I try to keep myself informed. The agency's a small club. I always walk around. I never let 48 hours go by without walking around (there are 1500 people here). It's easy to see at a glance who's OK and who's not. First of all, if a designer's creativity goes down, there must be a problem. A designer's not a machine. They don't always produce ideas of the same quality. Nonetheless, a top designer produces a certain number of great ideas every year. If suddenly the number goes down over a year or two, it means there's some sort of problem and I try to solve it. I think that it's the sine qua non condition of being a good manager. I was talking earlier about Sarkozy. His great strength when he was Home Office minister in 2002-2004 was that he was in the field. Before making his big police reform he gathered all the cops in France in huge locations and for an hour he explained to them the reforms that were going to be made and he gave them an hour to tell him what they expected of him. He's not from my party. I really wish he was a man from the 
Left! But his method: that's modern politics. It's also modern management.

I hate company boards that stay in their ivory towers when things should be completely transparent. I hate CEOs who shut themselves away in their offices, who never speak, who keep you waiting 3 months when you just want to see them for 3 minutes and who never shake hands with the people who pay them because who pays managers? The guys who work for them! So, managers should be at their service. What's really wrong with the system is that we don't vote for managers. This is where real progress has to be made. There are some companies that evaluate their CEOs. I find this really healthy. It means leaders can say to themselves: "I'm up to standard or I'm not up to standard," or "I must improve" and I think that if 1 day nobody wants you to be the leader anymore you should get out, otherwise you'd be betraying your company.

Interviewer: How do your colleagues see you?

JS: One always sees people better through their failings than through their qualities. Cecil B. DeMille said "you become a star for your weaknesses, not for your qualities." So, I think that they must probably call me a megalomaniac, which in fact I am, more for the media than in my personal life. Then, they probably notice a Manichean side in me that sees only black and white and is incapable of having the same gradation of judgment or finesse as them. The third thing they probably would say is: "Who's this old fart who has lost all touch with modernity and who's been going on about the same things for 40 years? When are we going to get rid of him? Turn the tap off! We can't take it any more!' 'And then, they'll say: "Now Séguéla has become a big shot. He's on the fifth floor in his corner office. Advertising's over for him. He's not really interested anymore. He's pretending."

Then, on the positive side they might say: "Well, the guy works hard. He's always here, 14 hours a day. And then three times a week he catches a plane to go at the other end of the world to get things moving. The guy does campaigns. They're still around. What about Citroën that's been with us for 2 years and is the fastest growing car brand in the world? What about Vuitton?"' I knew Vuitton when it had one shop, 40 years ago! There was one shop in Nice and one in Paris. Today it's one of the top brands in the world. I knew Lacoste when it was really small. It has grown by $10 \%$ each year. I knew Airbus when it was just starting. Now Airbus is huge. Therefore they'll say: "Well, we don't know how, but this guy gets results so perhaps we should listen to him." Then they'll say: "He's generous, yes. He knows how to listen. Every time we ask him something he bends over backwards to help."

Interviewer: What about your emotions and mood?

JS: I'm not moody anymore. I used to be moody until I was 50. I think that's when I realized that I tended to have terrible fits of anger. I used to jump on tables, to scream, to rant and rave, to become white with anger... always for creativity of course. Then, I realized that none of this made things go any faster. Now, I prefer gentleness, listening, sharing, going forward together, with humility.

But I think that when you're a designer, you have to have a touch of madness, megalomania, because I believe that you can be humble and megalomaniac at the same time. You see, in my case, when I'm doing a campaign I think that it's the best one in the world, otherwise I wouldn't go out and sell it, l'd try to do another one. How can I tell a client: "Well you see I've done a campaign but, in all modesty, I would say that perhaps it's not the best one?"' NO!!! I jump on the table and I say: "Nobody in the world will do a better campaign than this one, for such and such a reason." However, if I lose afterwards, I'll admit: "I was useless."

When you lead creative people, you should speak to your designers in designer terms. You should use their words, their language, like what they like, share their evenings, see their films, and it's only like this that I think you can get things moving. Not with anger. But you have to be totally demanding. You have to be present in everything and at every level of a campaign as well as being demanding with all those taking part in a campaign.

Interviewer: What about your designers' emotions?

JS: I think that it's always wrong not to ask people around you to be themselves. My office is the only one in the agency that is completely transparent and the door is always open. Any designer who has an idea, who has a problem, knows they can come in and that they don't have to knock. Whoever's in my office, even if it's the French President - and that's already happened to me in the past - a creative comes in and says they have a problem, l'll tell my visitor: "I'm sorry, stay here, we'll solve the problem together," and I try to react immediately. Of course, I'm not saying that I interrupt my conversation for an hour, but I want to give that creative those five vital minutes that they need straightaway. I listen to them and then we make an appointment immediately; I totally believe in this kind of openness. I also believe in spatial openness. You don't have to walk through my secretary's office to get into mine. You come into mine first. In my old office, you'd even had to go through my office to go see my secretary, and I had actually done this on purpose because I hate those self-important office organizers who cut you off from the problems of the people who work for you. You must never forget those who work for you because all the prizes you can see here (Jacques Séguéla points to all the advertising trophies that he has received) are not mine, they're ours. I tried to contribute my part but obviously, on my own, I wouldn't have gotten anywhere near those. Therefore it's normal that $80 \%$ of my time should be for them, and $20 \%$ for my clients.

An idiot standing up is worth more than 10 intellectuals sitting down. Emotion only works if it is converted into action. If emotional intelligence means gazing at your navel, and thinking that because you have emotions you're an artist, that you should live closed-in on yourself, and create for yourself and not for others, then emotional intelligence is negative and it's the worst kind of intelligence. Emotion only has a value if you know how to convert it into action. The job of an advertising executive involves taking an emotion from inside themselves and converting it into actions that are campaigns, which in just 30 seconds will touch the emotions of a consumer who will transmit it to another consumer, and it'll have a snowball effect throughout the world and it'll then result in a brand becoming stronger. One of the problems with the notion of emotional intelligence is that it puts on equal footing two opposing words, emotion and intelligence. But I believe that one should be stronger than the other. You can't be both "intelligent" and "emotional"; you can't be both "right-wing" and "left-wing". You have to choose which camp you're in. I 
chose the emotion camp, but then I dare say that I'm not that intelligent, which hasn't prevented me from succeeding, and from being happy. You know, I don't see many intelligent people who are happy. I wonder whether intelligence is the real virtue that should lead the world or whether it's rather the heart and action that should replace intelligence.

\section{Discussion}

Séguéla's interview touches upon a large number of themes useful in leading creative people. Many of these themes can be connected to existing leadership and management theories. We try to do so in the following paragraphs.

\section{The role of emotional intelligence in leading creatives}

Séguéla emphasizes the importance of emotional intelligence $(E Q)^{6}$ and emotion in creativity and in leading creatives. These assertions are consistent with existing theories. Emotions are assumed to play an important role in the creative process (Getz and Lubart, 1997; Lubart and Getz, 1997), and EQ has been identified as a critical skill for leaders of creative people (Zhou and George, 2003). For Séguéla, EQ helps leaders of creatives in at least three ways.

First, it allows leaders to legitimize emotion in the workplace. Traditionally, the corporate context is not open to emotion, especially in Cartesian France. Yet, emotions are key to the creative process. Séguéla thus makes it his job to enable creatives to be emotional by modeling the way.

Second, EQ helps leaders of creatives to empathize with them and understand them. He sees it as his role to keep his creatives happy and help them solve the work-related or personal problems that could block their creativity. He sees himself at their service, a philosophy reminiscent of servant leadership (Greenleaf, 2002). Part of his routine is to walk around the agency to keep an eye on his creatives and help those he diagnoses as unhappy, a technique reminiscent of management by walking around (Peters and Waterman, 1982). Keeping people happy has been shown to enhance creativity (Isen et al., 1985; Bolte et al., 2003).

However, Séguéla also recognizes using pressure tactics to keep his creatives on their toes. Consistent with this point, some studies have found that under certain conditions, negative, rather than positive, mood can facilitate on the job creativity in organizations (George and Zhou, 2002). Interestingly, Séguéla does not see a contradiction between keeping his employees happy and appropriately expressing negative emotions and applying pressure. His style thus provides an interesting integration of positive psychology themes (Cameron et al., 2003) and the more provocative view that leaders must sometimes intimidate their employees to obtain superior performance (Kramer, 2006).

Third, EQ helps leaders of creatives sell their ideas by seducing clients and stakeholders. According to Séguéla,

\footnotetext{
${ }^{6}$ Emotional intelligence is the ability to perceive emotions, to access and generate emotions so as to assist thought, to understand emotions and emotional knowledge, and to reflectively regulate emotions so as to promote emotional and intellectual growth (Mayer and Salovey, 1997).
}

one of his key roles is to sell the good ideas of his creative team. This is consistent with one of the key skills of leaders of creatives identified by Mumford et al. (2002) - promoting ideas. Séguéla declares himself ready to die if he has not sold a good idea, and according to him, a good salesman primarily relies on emotion and EQ. Indeed, Séguéla has an unprecedented record in advertising and sales. His campaigns have substantially helped to build such iconic brands as Louis Vuitton and Lacoste in France and around the world.

\section{The role of emotional contagion in advertising}

Beyond EQ, Séguéla emphasizes the importance of "emotional contagion"'. Emotional contagion is defined as the transfer of a sender's emotions to receivers (Barsade, 2002; Hatfield et al., 1993; Schoenewolf, 1990). Specifically, the emotions expressed by the sender cause the receivers to perceive and then feel them. Emotional contagion can occur unconsciously, when the receivers automatically imitate the sender's emotions (Barsade, 2002), or consciously, when the receivers imitate the emotions displayed by a higher status sender.

When advertising executives translate their emotions into successful advertising campaigns, these emotions will transfer from customer to customer, in a "snowball effect." Indeed, research has shown that service experience is prone to emotional contagion between providers and customers (Hatfield et al., 1994; Douglas Pugh, 2001).

Séguéla uses emotional contagion himself to manipulate his creative team. First, he expresses positive emotions to cheer his creatives up when they feel depressed. Second, he expresses negative emotions such as anger to induce pressure to increase creatives' performance. This is consistent with research that has shown that emotional contagion is more likely to occur in the leader-to-followers direction than in the followers-to-leader direction (Anderson et al., 2003; Cherulnik et al., 2001; Sy et al., 2005).

\section{Emphasis on action and intuition over thought}

Another theme that emerges from Séguéla's interview is the importance of action as opposed to reflection. Séguéla laments France's Cartesianism and preference for contemplation over action. He describes himself as reacting first, and thinking after, and calls for people to react more and think less. This is reminiscent of Weick's work on sensemaking and mindfulness (Weick and Sutcliffe, 2006; Weick, 1995). Emphasis on action allows Séguéla to better summarize important ideas in a catchy way that will speak to the customers' guts, a key skill in advertising, and in a world where consumers and voters have ever-shorter attention spans. It also allows him to choose among the large amount of ideas that are created. A big part of his job, he says, is to select the ideas that will be produced into campaigns, which is also one of the key skills of leaders of creatives identified by Mumford et al. (2002).

Alongside action, Séguéla admits relying a lot on his intuitive judgment to make decisions. Intuition, a concept that is gaining legitimacy in management research (Coget and Keller, 2010; Dane and Pratt, 2007; Sinclair and Ashkanasy, 2005), can be defined as a rapid, non-conscious process that 
produces affectively-charged judgments through holistic associations (Dane and Pratt, 2007). While it has been recognized that intuition can lead to faster and more accurate decisions than rational decision-making, one of the most pressing questions about intuition has been to determine the conditions under which the outcome is superior. Dane and Pratt (2007) have hypothesized that it is mainly expertise in the domain of knowledge within which a decision is made that ensures that intuition leads to superior outcomes than rational decision-making. Indeed, research on expert decision-making has clearly established that repeated exposure to specific types of problems through practice and training is related to the ability to excel in a domain of activity (Ericsson and Charness, 1994). Chess masters, for instance, who typically acquire their expertise over 10 years or more, have been shown to be able to reproduce the layout of pieces from an actual chess game shown briefly to them with $95 \%$ accuracy, while novices did so with only $25 \%$ of accuracy (Chase and Simon, 1973). Séguéla confirms these findings: he attributes his ability to recognize the best ideas to his 40 years experience during which he committed or witnessed mistakes being committed several times over.

Nonetheless, Séguéla also emphasizes openness. He will go against what his experience tells him if his "heart" goes for an idea that has failed before. Séguéla's openness to his emotions and his inner life may allow him to capture the zeitgeist and recognize ideas for which an audience is ripe.

\section{Modeling the way}

Part of Séguéla's success in leading creatives is his own creative genius, and the mythical success he has acquired in advertising in France. Séguéla clearly models the way for his creatives. This is consistent with previous research that states that leaders of creatives should be creative geniuses in their own right (Goffee and Jones, 2007; Mumford et al., 2002). It is also consistent with charismatic leadership theory in which leaders partially derive their power from heroic successes (Shamir et al., 1993; Weber, 1968). However, as Séguéla points out, charismatic leaders are very susceptible to failure. If they fail too often, they could loose their special status, and thereby lose their followers.

\section{The importance of the cultural context}

A final theme that we noted in Séguéla's interview is the importance of national culture as a moderating variable. While his account of how creatives should be led is reasonably consistent with the existing literature (e.g. Amabile and Khaire, 2008; Florida and Goodnight, 2005; Goffee and Jones, 2007; Mumford et al., 2002), the French context seems call for slightly different actions than the American context. Throughout the discussion, we referred to the importance of Descartes in French culture, who decidedly influenced the French to prefer thought over feelings and action. Séguéla's preference for emotion and action over rationality is much more strongly emphasized than it might be in the USA as a reaction against French Cartesianism. A practical conclusion for French leaders of creatives is therefore that they need to spend more time liberating them from Descartes' straight-jacket and encourage them further to jump to action and to listen to their emotions than their American counterparts.

\section{Conclusion}

Séguéla's 40 years of experience have given him an understanding of what creatives need, summed up in three inter-related points. First, once given an initial direction to focus on, creatives need freedom; for brainstorming and concept creation, and from distractions, both external and internal. Interested and empathetic leadership allows Séguéla to notice signs of distraction in his creatives and take steps, when possible, towards solutions.

Second, due to the personal focus needed in creativity, passion, motivation and identification with the project are necessary. Séguéla is himself passionate about his field and inspires others to be so, motivating them positively in this way, and negatively by applying pressure or criticism when necessary. Séguéla acknowledges the self-identity of his creatives by treating them as valued and skilled members of a symbiotic team, offering decisive opinions - yes, this is a good direction, or no, don't waste your valuable time and skills on that, go another way.

Third, creatives need decisiveness in direction and stopping points. Passion in creativity may lead to obsessiveness or overworking a concept. Séguéla offers a firm stopping point in acknowledging the roles both he and his creatives play in selling an idea - having done your part and given me a great idea to sell, now you are done and it's my job to take your great idea and sell it.

We were struck by the richness of Séguéla's interview and charmed by him. His leadership style can be related to a hodge-podge of leadership and management theories, which might not normally be cited together. Nonetheless, we like this witch's brew of theories. Practice does not know the boundaries that academia places between theories. Practitioners, like Séguéla, do what works. We hope to have contributed to research on how to lead creatives with examples from this flamboyant practitioner.

\section{References}

Amabile, T. M. (1983) The social psychology of creativity: A componential conceptualization. Journal of personality and social psychology 45(2), 357-376.

Amabile, T. (1996) Creativity in context. Westview Press, Boulder, CO.

Amabile, T. M., Conti, R., Coon, H., Lazenby, J. and Herron, M. (1996) Assessing the work environment for creativity. Academy of Management Journal 39(5), 1154-1184.

Amabile, T. M. and Khaire, M. (2008) Creativity and the role of the leader. Harvard Business Review 86(10), 100-109.

Anderson, C., Keltner, D. and John, O. P. (2003) Emotional convergence in close relationships. Journal of Personality and Social Psychology 84(5), 1054-1068.

Barsade, S. G. (2002) The ripple effect: Emotional contagion and its influence on group behavior. Administrative Science Quarterly 47(4), 644-675.

Bolte, A., Goschke, T. and Kuhl, J. (2003) Emotion and intuition: Effects of positive and negative mood on implicit judgments of semantic coherence. Psychological Science 14(5), 416-421.

Brown, S. L. and Eisenhardt, K. M. (1997) The art of continuous change: Linking complexity theory and time-paced evolution in 
relentlessly shifting organizations. Administrative Science Quarterly 42(1), 1-34.

Cameron, K. S., Dutton, J. E. and Quinn, R. E. (2003) Positive organizational scholarship: Foundations of a new discipline. Berrett-Koehler, San Francisco, CA.

Chase, W. G. and Simon, H. A. (1973) Perception in chess. Cognitive Psychology 4, 55-81.

Cherulnik, P. D., Donley, K. A., Wiewel, T. S. R. and Miller, S. R. (2001) Charisma is contagious: the effect of leaders' charisma on observers' affect. Journal of Applied Social Psychology 31(10), 2149-2159.

Coget, J. and Keller, E. (2010) The critical decisions vortex: Lessons from the emergency room. Journal of Management Inquiry 19(1), 56-67.

Csikszentmihalyi, M. (1996) Creativity: Flow and the psychology of discovery and invention. Harper Perennial, New York.

Dane, E. and Pratt, M. (2007) Exploring intuition and its role in managerial decision-making. Academy of Management Review 32(1), 33-54.

Douglas Pugh, S. (2001) Service with a smile: Emotional contagion in the service encounter. Academy of Management Journal 44(5), 1018-1027.

Drazin, R. and Schoonhoven, C. B. (1996) Community, population, and organization effects on innovation: A multilevel perspective. Academy of Management Journal 39(5), 1065-1083.

Ericsson, K. A. and Charness, N. (1994) Expert performance. American Psychologist 49(8), 725-747.

Feldman, D. H. (1999) The development of creativity. In Handbook of creativity ed. R. J. Sternberg, pp. 169-188. Cambridge University Press, Cambridge, England.

Florida, R. and Goodnight, J. (2005) Managing for creativity. Harvard Business Review 83(7), 125-131.

George, J. M. and Zhou, J. (2002) Understanding when bad moods foster creativity and good ones don't: The role of context and clarity of feelings. Journal of Applied Psychology 87(4), 687-697.

Getz, I. and Lubart, T. (1997) The emotional resonance model of creativity. Taylor Francis, In Creativity at work. New York, NY.

Goffee, R. and Jones, G. (2007) Leading clever people. Harvard Business Review 85(3), 72.

Greenberg, E. (1992) Creativity, autonomy, and evaluation of creative work: Artistic workers in organizations. Journal of Creative Behavior 26(2), 75-80.

Greenleaf, R. K. (2002) Servant leadership: A journey into the nature of legitimate power and greatness. Paulist Press, New York.

Harrell, A. M. and Stahl, M. J. (1981) A behavioral decision theory approach for measuring McClelland's trichotomy of needs. Journal of Applied Psychology 66(2), 242-247.

Hatfield, E., Cacioppo, J. and Rapson, R. L. (1994) Emotional contagion. Cambridge University Press, Paris.

Isen, A. M., Johnson, M. M. S., Mertz, E. and Robinson, G. (1985) The influence of positive affect on the unusualness of word associations. Journal of Personality and Social Psychology 48(6), $1413-1426$.

Kramer, R. M. (2006) The great intimidators. Harvard Business Review 84(2), 88-96.

Lubart, T. and Getz, I. (1997) Emotion, metaphor, and the creative process. Creativity Research Journal 10(4), 285-301.

Mayer, J. D. and Salovey, P. (1997) What is emotional in-telligence? In Emotional development and emotional intelligence. Implications for educators, (eds) P. Salovey and D. Sluyter, pp. 3-31. Basic Books, New York.

Mumford, M. D., Scott, G. M., Gaddis, B. and Strange, J. M. (2002) Leading creative people: Orchestrating expertise and relationships. The Leadership Quarterly 13(6), 705-750.
Nystrom, H. (1990) Organizational innovation. In Innovation and creativity at work: Psychological and organizational strategies, (eds) M. West and J. Farr, pp. 143-162. Wiley, New York.

Oldham, G. R. and Cummings, A. (1996) Employee creativity: Personal and contextual factors at work. Academy of Management Journal 39(3), 607-634.

Peters, T. and Waterman, R. (1982) In search of excellence. Harper \& Row, New York.

Rostan, S. M. (1998) A study of the development of young artists: The emergence of an artistic and creative identity. Journal of Creative Behavior 32, 278-301.

Shamir, B., House, R. and Arthur, M. (1993) The motivational effects of charisma: A self-concept based theory. Organization Science 4(4), 577-594.

Schoenewolf, G. (1990) Emotional contagion: Behavioral induction in individuals and groups. Modern Psychoanalysis 15(1), 49-61.

Sinclair, M. and Ashkanasy, N. M. (2005) Intuition: Myth or a decision-making tool. Management Learning 36(3), 353-370.

Sy, T., Côté, S. and Saavedra, R. (2005) The contagious leader: Impact of the leader's mood on the mood of group members, group affective tone, and group processes. Journal of Applied Psychology 90(2), 295-305.

Tushman, M. L. and Anderson, P. (1986) Technological discontinuities and organizational environments. Administrative Science Quarterly 31, 439-465.

Tushman, M. L. and O'Reilly, C. A. (1997) Winning through innovation: A practical guide to leading organizational change and renewal. Harvard Business School Press, Cambridge, MA.

Weber, M. (1968) On charisma and institution building: Selected papers. University of Chicago Press, Chicago.

Weick, K. E. (1995) Sensemaking in organizations. Sage, Foundations for organizational science. Thousand Oaks.

Weick, K. E. and Sutcliffe, K. M. (2006) Mindfulness and the quality of organizational attention. Organization Science 17(4), 514.

Zhou, J. and George, J. M. (2003) Awakening employee creativity: The role of leader emotional intelligence. The leadership quarterly 14(4-5), 545-568.

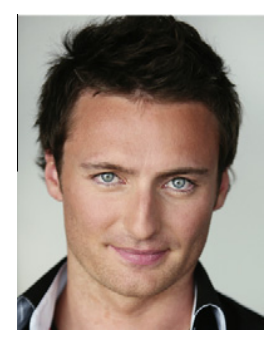

CHRISTOPHE HAAG is an Associate Professor of Organizational Behavior at EMLYON Business School. His research focuses on emotional intelligence and on the cathartic and catastrophic role of emotion in the intuitive decision making process.

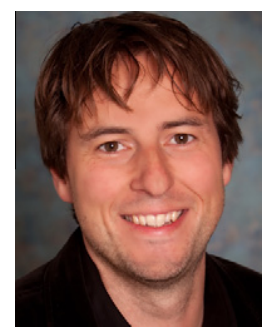

JEAN-FRANÇOIS COGET is an Assistant Professor of Management at the Orfalea College of Business at CalPoly, San Luis Obispo, where he teaches Organizational Behavior. He earned his Ph.D. from the Anderson School at UCLA, and was previously a faculty member at HEC Paris. His research interests include emotions, intuition, and charismatic leadership. His overarching professional goal is to create and disseminate actionable knowledge that can help managers-citizens to organize a productive, creative, ethical, and sustainable cooperation among people. 